IBT Journal of Business Studies

Volume 14(2), 117-131, 2018

\title{
Influence of Quality Management Practices On Employees' Perception of Organizational Effectiveness at Ks\&Ew
}

\author{
Burhan Ahmad ${ }^{1}$ \\ Rafique Ahmed Khan ${ }^{2}$
}

\begin{abstract}
Purpose: The research was conducted with the purpose to identify influence of various Quality Management Practices (QMPs) on organizational effectiveness at Karachi Shipyard and Engineering Works (KS\&EW). The QMPs selected for the research included Customer focus approach', Education and Training, Continuous Improvement, Teamwork, and Top Management Commitment.

Methodology: Adopting deductive approach, hypotheses were first formulated after extracting independent variables from the relevant literature. A research instrument in the form of a wellstructured questionnaire was developed for collection of quantitative primary data from a sample of 80 respondents. The collected data were then treated by applying correlation and regression analysis tools.

Findings: The impact of independent variables on dependent variable was established. Findings of the study indicate that there is a positive impact of various practices (independent variables) on organizational effectiveness, although with varying degree. Overall, employees have a positive perception about existing TQM practices and believe that these are quite effective to achieve desired objectives.

Implications: This study is considered quite beneficial for the management of $K S \& E W$ for ascertaining influence of quality management practices on organizational effectiveness. Managers of the organizations of other industries and academia may also find the study useful and can benefit from its findings. In the end some useful measures have been recommended to enable KS\&EW for further improving organizational effectiveness.
\end{abstract}

Key words: Quality Management, Customer Focus, Education and Training, Continuous Improvement, Teamwork, Top Management Commitment, Organizational Effectiveness

1- Bahira University, Karachi, Pakistan. burhan4531@gmail.edu.pk

2- Bahira University, Karachi, Pakistan. rak.bukc@bahria.edu.pk 


\section{INTRODUCTION}

Now-a-days quality is prime focus of all organizations in all business fields. Quality products and services have always been a natural choice of every individual, community or an organization. International Organization for Standardization (ISO) defines quality as "the degree to which a set of inherent characteristics fulfills requirements" (Murali Chemuturi, 2013). Different quality gurus have defined quality in different ways. According to Gray, Larson and Desai, (2010), quality means fitness for use. In the present era which is characterized by cut throat competition (Al-Shobaki et al., 2010), one of the biggest challenges is the customer satisfaction and their sustained retention which ultimately leads to organizational effectiveness. In order to be in top ranking organizations one has to produce and maintain quality products or services (Vidyarthi et al., 2009). Management of all kinds of activities intend to produce quality product and services by different types of organizations is indeed the Quality Management. Quality Management is the mustering and managing various activities performed to produce quality products/ services by the performing organizations. QM as defined by researchers is a set of guiding principles and management style adopted by managers in organizations to improve competitiveness and organizational performance (Ali Bakhit Jaafreh, 2012). QMS is a set of harmonized activities to direct and control the performing organization so as to continually improve the effectiveness and efficiency of its performance (Department of Trade and Industry, 2000). There are countless reasons for organizations to go on for implementation of quality management system. For example, well defined and documented procedures helps in maintaining consistent throughput of the organization, continuous measurement of quality making it possible to be aware about deviations from mean and to take necessary corrective measures; besides suitable preventive measures through careful analysis of the root causes to prevent recurrence (Bjerke et al., 2007). Effective implementation of QMS improves organizational effectiveness, long-term profitability and financial returns and ultimately results in improved quality performance (Shiv Kumar Sharma et al, 2014).

In order to adapt to the best quality management practices, every organization creates a culture where employees at all levels are conscious of the standard quality requirements vis-à-vis availability of various quality tools (Rawan Al-Ettayyem \& Zu'bi M. F. Al-Zu'bi, 2015). In an effort to minimize quality issues and improve overall effectiveness, organizations take a number of measures to maintain a sustained competitive edge in the industry. The implementation of QMS improves competitive advantage as well as satisfaction of both the customer and employee (De Vries and De Jong 2002). This research was conducted at Karachi Shipyard and Engineering Works (KS\&EW) which is a shipbuilding and ship-repair organization and. is the only organization of unique significance in the country.

\section{Problem Statement}

Quality management is an emerging concern for almost all leading organizations who believe in maintaining a competitive edge through customer satisfaction. Almost all leading organizations take necessary measures to ensure compliance to established quality standards. However, it is a challenging task since it is related to continuous employee development and job satisfaction. Any deviation from standard quality measures leads to quality related problems which in turn negatively affect overall organizational effectiveness (Kim-Soon Ng,2012). KS\&EW, being sole player of ship building industry, is a ship manufacturing organization that needs to maintain highest quality standards. After obtaining ISO certification in the recent past, the business activity has gained momentum and it is expected to further expand. However, in the recent past, some defects were observed during trials of the newly manufactured small vessels which were attributed to lack of proper conformity to quality standards. Due to development of these defects, some delays took place and organization had to spend additional resources. Through this study, efforts were made to evaluate 
existing TQM practices at KS\&EW and also to find out the perceived influence of these practices on organizational effectiveness at KS\&EW.

\section{Research Questions}

In light of the problem statement, following research questions were set:

- What is the impact of different components of quality on organizational effectiveness?

- What is the relationship between different components of quality management and organizational effectiveness?

- What is perceived impact of different quality practices on organizational effectiveness?

\section{Research Objectives}

Following research objectives were formulated:

- To examine relationship of various quality management practices with organizational effectiveness.

- To find out impact of quality management practices on organizational effectiveness.

- To propose suitable measures to the organization for improving quality management practices with an aim to enhance organizational effectiveness.

\section{LITERATURE REVIEW}

\section{Significance of Organizational Effectiveness}

The word 'organization' has been derived from the Greek word "organon" which means a section or a segment for a particular job. Being a group of people, an organization allocates tasks amongst various personnel and segments for achieving a collective goal or a set of goals. The concept of Organizational effectiveness determines effectiveness of an organization in achieving the intended outcomes. Thus organizational effectiveness also relates to the efficiency with which the organization meets its objectives (Corredor, P., and Goñi, S., 2011). The yard stick for measuring organizational effectiveness is generally in terms of its net profitability, in comparison with its anticipated profitability (Jorge Morales Pedraza, 2014).

Organizational Effectiveness is a methodical and universal method of continuously improving performance of organization. Methodical approach relates to structure and procedures for implementation of strategy whereas universal approach keeps the complete organization in focus while dealing with performance and improvements in the outcome (Paul Cole-Ingait, 2010). The success of organizational effectiveness also lies in paying attention to the feedback provided by customers and employees and subsequently taking necessary measures accordingly (Luke Talbot, 2016). It is not the responsibility of managers alone but all organs of the organization are to play their part so as to contribute towards organizational effectiveness (Dongli Zhang \& Sarah Jinhui Wu 2014). Organizational effectiveness means that the performing organization delivers a product or service with reduced cost. The required outcome will be dependent on the organizational goals and objectives. A proficient organization will yield a product devoid of waste (Mohamad Kamal, Mohamad Dasuki \& Dr. Rizal Razalli, 2013). For the organizations who have the ability to demonstrate both the efficiency as well as the organizational effectiveness, they achieve their objective of profit making by delivering products/ services without waste (Abdul Rahman, M.N. and Tannock, J.D.T. 2005).

Organizational effectiveness enhances business performance over a wide range of criteria. Some of 
the critical components of organizational effectiveness may include financial performance, planning, organizational structure and observance of core values (Faisal, T., Rahman, Z. and Qureshi, M.N., 2011). Organizations should list down criteria to assess their effectiveness. Thus every organization should have its own list of criteria so as to measure effectiveness through self-evaluation and both the organizational management and the work force understand the objectives, goals and their organizational performance. Moreover, through self-assessment of organizational effectiveness, employees reconnect with the primary mission of the organization. Furthermore, employees may grow higher in hierarchy and develop strong sense of loyalty, purpose, and devotion to the profession while working creatively and discovering new business strategies to overcome weak areas. (Jorge Morales Pedraza, 2014).

\section{Quality Management Practices}

The philosophy of Total Quality Management (TQM) provides guidelines or principles for continuous improvement of the quality of product or service. In view of Chong, V.K., and Rundus, M. J. (2004), the pursuit for quality is just not a goal it is somewhat a journey. It is test for performing organizations to ensure provision of products and/or services meeting (and exceeding) customer needs and expectations at the lowest possible cost all the times. Over the years, various Quality gurus have considerably contributed towards the development of quality management systems. The role of quality pioneers had a great impact on later work related to TQM (Ali Bakhit Jaafreh, 2012). The participation of top leadership is very crucial and it should be clearly visible as it foster achieving of organizational goals. According to Juran, Quality Control (QC) should be an indispensable segment of management functions. Moreover, the culture prevailing in the organization and the management itself play a key role in ensuring quality management (Saravanan and Rao (2007). QC is not restricted to QA department but includes all departments of the organization, focusing on a reasonable client orientation - both internal and external customers (K. Shahriar Iqbal, N. M. Golam Zakaria and Kh. Akhter Hossain, 2013).

According to Jaafreh and Al-abedallat, (2013), the Quality Management Practices and Organizational performance are correlated with each other and QM Practices have a positive impact on organizational performance. There are formal or institutionalized models for assessment of quality, providing guidelines for utilization andto carry out self-assessment of their quality practices. In this regard, there are numerous Quality Awards in the world for assessment of TQM implementation practices. These include, Deming Prize in Japan, Malcolm Baldrige National Quality Award in USA and European Quality Award (EFQM) in Europe etc. These models think of an extensive variety of management actions, conduct and the methods having direct bearing on quality of product/ service and deliver a valuable system to assess TQM implementation practices, look for improvement opportunities, and the final product/ service. A number of researchers in their studies have established that performance improves with effective implementation of quality (Prajogo and Sohal, 2006), Hendricks and Singhal (1997, 2001), Kaynak (2003), Powell (1995), Christiansen and Lee (1994), Kanji and Tambi (1999), Rao et al., (2000), Powell (1995) and Easton and Jarrell (1998)\}.

Psomas and Fotopoulas (2009 and 2010), discovered critical success factors (CSFs) like top management support, teamwork, involvement of People in the quality management system, customer focus, training, process and data quality management, and supplier quality management which lead to improvement in quality, profitability, customer satisfaction, market share, reduction of defects and product or service price. After extensive literature survey, following five QMPs have been selected for development of framework for this study. These elements of QMPs include, Customer Focus, Education and Training, Continuous Improvement, Team Work and Commitment of Top Management which have been discussed in ensuing paragraphs (Prajogo and Sohal, 2006). 


\section{Customer Focus Approach}

In the present competitive era, which is characterized by customer delightedness, the executives determine how much customer centric an organization should be, based on their experience and the brand name (Kate Leggett, 2016). The term "customer focus" is given full attention/ priority to produce product or services to the expectations of the customers (Diamantopoulos, A. and Winkelhofer, H. M. 2001). Customer focus approach emphasizes on maintaining quality throughout the designing and production process for meeting or exceeding requirements of customers. In such organizations, the production and delivery of goods/ services are guided by clients' interest which comes first and regarded foremost priority (Greg Baker, 2014).

There is a solid connection between profitability, high quality products or services and the customer satisfaction. The customer satisfaction is reflected from the perception of clients. If they perceive that their requirements are fulfilled by company's products or services, they will be satisfied (Zehir, C., Ertosun, Ö., Zehir, S., \& Müceldilli, B. 2012). Organizations essentially recognize the importance of customer relationship to measure their requirements and expectations. They should include clients in quality improvement endeavours and should identify the client's satisfaction (Prajogo \& Sohal, 2003; Flynn, 1994, 1995; Powell, 1995; Ahire, 1996; Black \& Porter, 1996). Numerous researchers believe in the significance of customer satisfaction while basing on Deming work who specified consumer main element of the production line, the quality of the product or service should be targeted on the current and future requirements of the consumer (Deming, 1986). It is understood that with the fulfillment of customers' expectations, the satisfaction increases which has direct bearing on the increase of sales and market share (Esin Sadikoglu, Hilal Olcay, 2014).

\section{Education and Training}

Education helps in fostering abilities of the mind and Training is aimed at imparting practical education and developing skills in certain fields/ professions. Training not only develops knowledge and skill but also improves the attitude and social behavior of employees (Pallavi P. Kulkarni, 2013). Consequently, the performance of organization improves substantially. The profitability of a firm is also dependent on the knowledge/ level of qualification of employees and their skill set which can be developed further through affording training and education opportunities on recurrent as well as on need basis (Kannan, V.R. and Tan, K.C. (2005).

It may however be noted that only training just cannot assure enhancement of organizational effectiveness because it is neither possible nor it can be guaranteed that the knowledge is transferred in entirety and applied to the work place effectively, yet the efforts invested for training do have positive effects on organizational effectiveness (Giron Kamonja, Yan Liang, Muhammad Tayyab Sohail, Shahzad Ahmad Khan, 2014).. It is paramount for firms to give due importance to personal grooming and development of skill/ expertise of their employees which lead to magnified productivity, enhanced efficiency and increased effectiveness of the organization. It also contributes to increased job satisfaction of employees Saman, Y . (2012). Trained employees achieve better performance of the organizations. In order to have pool of efficient and skilled employees, companies educate their staff by providing training in newer skills and knowledge resulting in efficient organization (Cervená, 2011). It is also worthy of consideration that training should address the needs of employees and conducive environment should be created to encourage employees for training and later on its application at work place.

In addition to the change in the employees, there is need to assess the method of training employed through feedback from trainees to see what they have learned; and accordingly design specific training program as per dictates of the requirements (Dongli Zhang \& Sarah Jinhui Wu, 2014). Training enhances overall performance of an organization in various ways (Pallavi P. Kulkarni, 2013). 


\section{Continuous Improvement}

It refers to enduring efforts for enhancement of products, services and processes etc. These endeavours may either be sought through "incremental" improvements over time or through "breakthrough" improvements at a sudden. There are three types of improvements (Jānis Priede, 2012). Continuous improvement is a steady and progressive but an endless change, while continual improvement is incremental change. Genesis of both sorts of improvements lies in a Japanese term 'Kaizen'. This Japanese philosophy means continuous improvement through involvement of all personnel of an organization ranging from top management till workers at workshop floor level (Thessaloniki, 2006). It is basically a step change and has a tendency to emerge out of chance revelations and could take years before being made, as illustrated below (European Quality Assurance in Vocational Education and Training):

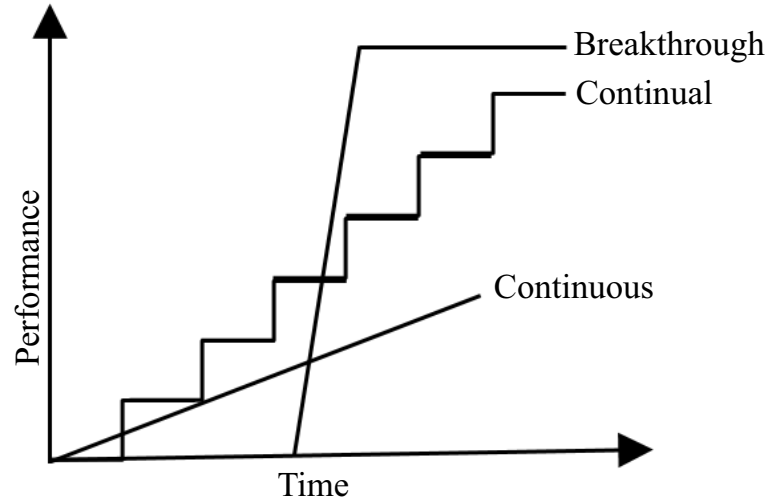

Figure .1: Types of Improvements (Source: Knowledge Hub, Chartered Quality Institute)

This concept describes that all possible facets of any operation can best be improved especially by those who are directly involved in those operations being well familiar and have the capability to exploit the opportunity and implement change for improvement (Gremyr, I., \& Elg, M., 2014). There are some more methods of continuous improvement which are also utilized extensively, i.e. Six Sigma, Lean production and TQM etc. These methods stress on employee involvement and teamwork; evaluating and schematizing processes; and minimizing deviations, deficiencies and cycle periods (Abdul Talib, H.H, Mohd Ali, K.A. \& Idris, F., 2014).

\section{Team Work}

Working together in group and striving for achieving a common goal can simply be termed as Team work. Though very critical for an organization, yet essentially required for staff to work in cohesion in all types of favorable or odd situations. In this QM practice, employees tend to cooperate with each other, help management through meaningful feedbacks and disregard all sorts of personal differences among themselves (Ataur Rahman, 2015). Since teamwork increases efficiency, it obviates need to employee additional staff in pursuit of higher productivity targets resulting in more revenue generation. Where the environment is conducive for teamwork, people assertively provide creative and unique ideas/ suggestions (Danny Samson, Mile Terziovski, 1998). The co-location of staff while producing an effective team environment afford opportunity for learning from each other's skill and experience besides it also helps them to enhance their both verbal and written communication skills. Teamwork builds trust amongst team members and encourages them to help others when needed, especially during challenging times. Stable and informal relationship between the parties, with 
informal line of communication, is one of the key practices for a strong teamwork and effective communication (Nursyamimi Shaari et al. 2014).

When employees work together as colleagues they perform well both on a particular team oriented project or in different departments as a routine; it enhances their productivity and morale. Conversely, if there is a difference of opinion amongst the team members, it inhibits teamwork, resulting in delay of projects, cost overruns and decrease in effectiveness of the job performed by them (Lisa McQuerrey, 2010). The team work spirit is a source of creating a conducive environment that encourages variety of team work factors among team members, i.e. cohesion, cooperation, respect, pride, commitment, confidence, adaptability, talent, management support etc. (Mazida Ahmad et al, 2014). It is therefore mandatory for project managers to make utmost efforts to develop cohesion amongst team members so that they stick together and remain united in pursuit of goals and objectives of their organization so as to attain higher organizational effectiveness.

\section{Top Management Commitment}

Top Management relates to those highest level executives who are at the helm of affairs of an organization and are responsible for making strategic decisions. They are to plan and execute strategies to fulfill client's needs and achieve organizational goals and objectives. Their responsibilities include: Establishment of quality policies, formulation and deployment of quality goals, provision of resources, facilitating training as per needs and improvement process etc. (Juran, 1988\&Gryna 1993).

A vast majority of the researchers is of the view that strong commitment of the higher level executives plays a vital role in achieving higher quality standards (Saraph, 1989; Flynn, 1994; Ahire, 1996; Juran, 1988; Anderson, 1995). Powerful leadership strives to streamline the firm's strategic direction so as to attain clients' satisfaction and company goals and objectives. It is rightly said that quality is decided in the boardroom; it cannot be instilled into shop floor without the initiative and commitment of top management (Davood Gharakhani et al., 2013).

\section{Theoretical Framework}

In the under mentioned figure, theoretical framework for the research is illustrated:

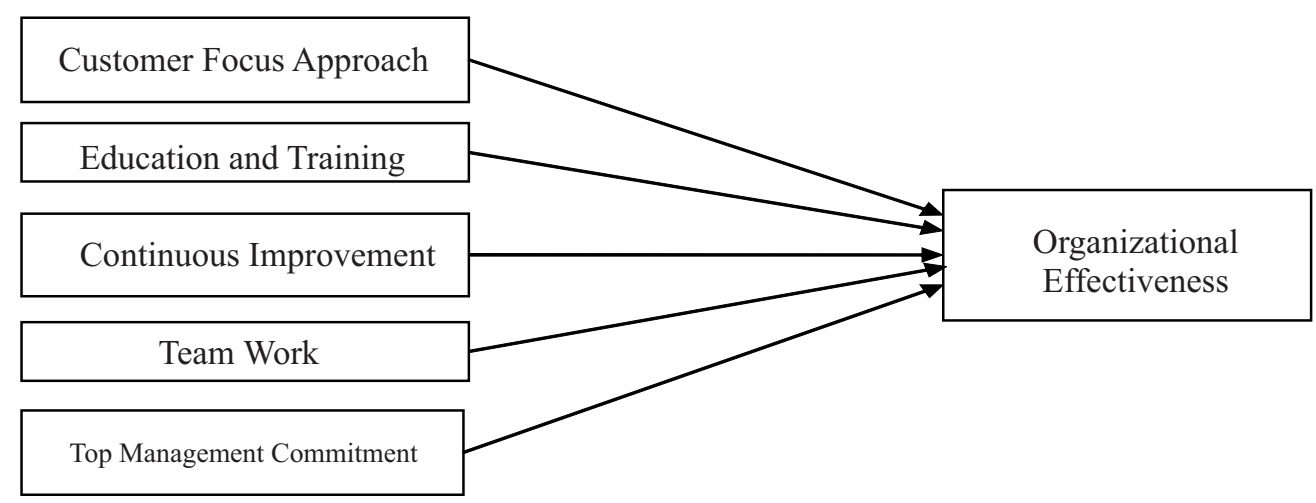

Figure. 2: Theoretical Framework (Developed by Author)

\section{Research Hypotheses}

H1: There is a significant influence of 'Customer Focus Approach' on organizational effectiveness. 
H2: There is a significant influence of 'Education and Training' on organizational effectiveness.

H3: There is a significant influence of 'Continuous Improvement' on organizational effectiveness.

H4: There is a significant influence of 'Teamwork' on organizational effectiveness.

H5: There is a significant influence of 'Top Management Commitment' on organizational effectiveness.

\section{RESEARCH METHODOLOGY}

This study is explanatory in nature as many such studies have been undertaken in the past. Deductive approach was adopted for the research whereby hypotheses were first developed after identifying suitable variables from the relevant literature. Hence, a theoretical framework was constructed, followed by preparation of a research instrument in the form of a well-structured questionnaire, on a Likert scale of 1 to 5 for collecting quantitative primary data. This is a correlational and causal study because it is intended to find out relationship between different variables with the dependent variable so as to establish the influence/ cause of independent variables on the dependent variable.

\section{Target Population}

The workers of high skilled level of Karachi Shipyard and Engineering Works (KS\&EW), also termed as 'HS-1', were taken as target population for the purpose of research as they significantly contribute to the capability and capacity of the yard to accomplish its goals in terms of its yield/ products etc. There are around 540 employees of target cadre.

\section{Sample Size and Sampling Technique}

The size of sample selected for the data collection/ analysis purposes, was of 80 which was calculated with the help of online formula/calculator:

$\mathrm{n}=$

$$
\frac{\mathrm{N}}{1+\mathrm{Nx}(\mathrm{e})^{2}}
$$

The description of the terms used in this formula is provided below:

$\mathrm{n}=$ represents the sample size

$\mathrm{N}=$ represents the population, $\mathrm{N}=540$

$\mathrm{e}=$ Represents the acceptable sampling error, $\mathrm{e}=0.1$

The sample size thus calculated is 540/6.4 $=84$ approximate

Out of 85 questionnaires that were distributed, 80 were returned in complete form and this number was used for statistical analysis. Hence return rate of filled questionnaires was $94 \%$ which is fairly good.

\section{Sampling Technique}

The sampling technique adopted here in this research was non-probability, convenience technique. It is due to this reason that the participants of target population were selected considering their ease of access. Moreover, sampling of appropriate participants best suited for the purpose of data collection. It was found that this technique was quite useful in approaching the respondents, who were easily available, during routine working hours.

\section{Research Instrument}

Data collection is very important step and needs much more concentration of the researcher because if this step is well engineered and taken correctly then the research results are more accurate. 
Questionnaire is one of the main and commonly used sources of primary data collection. Data was obtained through well-structured questionnaire, based on different variables of research, duly filled by the respondents. The questionnaire was comprised of two main parts; one is 'Demographic Part' and 'Questions Part'. First part provides the individual profile of respondent whereas the second part is the key part which has been provided with main constructs of the variables. Simple statements were given with five options Strongly Agree (SA), Agree (A), Neutral (N), Disagree (D) and Strongly Disagree (SD) have been provided to answer these questions.

\section{Data Treatment and Interpretation}

Upon collection of the data, it was then treated by applying statistical tools including Pearson's Correlation and Regression with the help of 'Statistical Package for Social Sciences (SPSS) version 22 '. After the conduct of detailed data analysis, the hypotheses were tested for their acceptance or rejection. The statistical results (tabular form) obtained through data analysis were interpreted for ascertaining relationship amongst the variables and determining impact of independent variables on organizational effectiveness.

\section{ANALYSIS}

Data collected from the respondents indicate that out of 80 respondents who replied to the questionnaire, 64 were male respondents and 16 were females. Out of these, $20 \%$ were undergraduates, $55 \%$ graduates and $25 \%$ respondents were masters.

\section{Test of Reliability (Cronbach's Alpha)}

This test was applied to test internal consistency of the items. It helps in improving the quality of the items in the instrument. When Cronbach's alpha reliability test value is greater than 0.7 , the items are considered to be reliable.

Table .1: Reliability Statistics

\begin{tabular}{|c|c|c|}
\hline INDEPENDENT VARIABLES & CRONBACH'S ALPHA & ITEMS \\
\hline Customer Focus Approach & .953 & 5 \\
\hline Education and Training & .974 & 6 \\
\hline Continuous Improvement & .856 & 5 \\
\hline Team Work & .970 & 5 \\
\hline Top Management Commitment & .875 & 4 \\
\hline Organizational Effectiveness & .864 & 4 \\
\hline
\end{tabular}

As indicated in the above table, Cronbach's Alpha value for 'Customer Focus' is 0.953 and the items were five. For 'Education and Trainings', Cronbach's Alpha value is 0.974 and there were six items. For third variable i.e. 'Continuous Improvement', Cronbach's Alpha is 0.856 , and there were 5 items. In 'Team Work', value of Cronbach's Alpha is 0.970 and there were five items. For the last variable i.e. 'Top Management Commitment', value of Cronbach's Alpha is 0.875 and there were 4 items. In case of dependent variable, Cronbach's Alpha value is .864 and there were four items. The above values of the Cronbach's Alpha Reliability test show that each variable has a value greater than 0.7 which means research instrument is reliable.

\subsection{Regression Analysis}

\begin{tabular}{|c|c|c|c|c|}
\hline \multicolumn{6}{|c|}{ Table.2: Model Summary } \\
\hline Model & $\mathrm{R}$ & R Square & Adjusted R Square & $\begin{array}{c}\text { Std. Error } \\
\text { of the } \\
\text { Estimate }\end{array}$ \\
\hline 1 & $.996^{\mathrm{a}}$ & .993 & .992 & .068 \\
\hline
\end{tabular}

a. Predictors: (Constant), Customer Focus Approach, Top Management Commitment, Continuous Improvement, Education \& Training, Team Work 
Values of $\mathrm{R}$ and $\mathrm{R}^{2}$ ( $\mathrm{R}$ square) are given in the table above. $\mathrm{R}$ shows simple correlation which is equal to 0.996 and indicates high degree of correlation. $\mathrm{R}^{2}(.993)$ denotes the amount of total variation in the dependent variable which can be explained by independent variables. Here, 99.3\% can be explained i.e. five chosen predictors have $99.3 \%$ impact on organizational effectiveness.

Table.3: ANOVA

\begin{tabular}{|c|c|c|c|c|c|c|}
\hline \multicolumn{2}{|c|}{ Model } & $\begin{array}{c}\text { Sum of } \\
\text { Squares }\end{array}$ & Df & Mean Square & F & Sig. \\
\hline \multirow{2}{*}{1} & Regression & 48.039 & 5 & 9.608 & 2087.986 & $.000^{\mathrm{b}}$ \\
\cline { 2 - 7 } & Residual & .341 & 74 & .005 & & \\
\cline { 2 - 7 } & Total & 48.379 & 79 & & & \\
\hline
\end{tabular}

The above table.3tells us about how correctly the regression equation fits the data (i.e. predicts the dependent variable).'Sig' column in 'Regression' row expresses that the dependent variable is significant. Since, the value of $p=0.000$, which is less than 0.05 ; it is deduced that the overall regression is statistically significant which in turn predicts the outcome variable.

\begin{tabular}{|c|c|c|c|c|c|c|}
\hline \multicolumn{7}{|c|}{ Table. 4: Coefficients ${ }^{a}$} \\
\hline \multirow{2}{*}{\multicolumn{2}{|c|}{ Model }} & \multicolumn{2}{|c|}{$\begin{array}{l}\text { Unstandardized } \\
\text { Coefficients }\end{array}$} & \multirow{2}{*}{$\begin{array}{c}\begin{array}{c}\text { Standardized } \\
\text { Coefficients }\end{array} \\
\text { Beta } \\
\end{array}$} & \multirow[t]{2}{*}{$\mathrm{t}$} & \multirow[t]{2}{*}{ Sig. } \\
\hline & & $\mathrm{B}$ & Std. Error & & & \\
\hline \multirow[t]{6}{*}{1} & (Constant) & -.305 & .048 & & -6.351 & .000 \\
\hline & Customer Focus & .140 & .039 & .133 & 3.614 & .001 \\
\hline & Education \& Training & .232 & .022 & .250 & 10.682 & .000 \\
\hline & Continuous Improvement & .200 & .037 & .183 & 5.443 & .000 \\
\hline & Team Work & .301 & .043 & .290 & 6.983 & .000 \\
\hline & $\begin{array}{c}\text { Top Management } \\
\text { Commitment }\end{array}$ & .191 & .020 & .195 & 9.744 & .000 \\
\hline
\end{tabular}

The table. 4 above shows that increase in one unit of customer focus will result in increase of organizational effectiveness by 0.140 units. Since $p<0.05$, therefore, impact of customer focus is clearly observed on organizational effectiveness. It is evident that increase in one unit of education and training will result in increase of organizational effectiveness by 0.232 units. Since $p<0.05$, therefore, impact of education and training is clearly observed on organizational effectiveness. In case of next variable, increase in one unit of continuous improvement will result in increase of organizational effectiveness by 0.200 units. Since $p<0.05$, therefore, impact of continuous improvement is clearly observed on organizational effectiveness. For the Team Work, increase in one unit of team work will result in increase of organizational effectiveness by 0.301 units. Since $p<0.05$, therefore, impact of team work is clearly observed on organizational effectiveness. Similarly, for Top Management Commitment, one unit of top management commitment will result in increase of organizational effectiveness by 0.191 units. Since $p<0.05$, therefore, impact of top management commitment is clearly observed on organizational effectiveness.

\section{DISCUSSION}

\section{Customer Focus Approach}

Findings of the analysis, with regard to customer focus, indicate that employees perceive that this aspect of TQM has a positive impact which is also significant. These findings are compatible with the results obtained by Kate Leggett, (2016) in his research. Employees perceive that once customers' voice is heard and their feedbacks are taken seriously with positive intent, customers feel satisfied. The customers begin to trust the firms who are looking after their interests and provide goods and services according to their needs and expectations. The same is supported by Zehir, C., Ertosun, Ö., Zehir, S., \& Müceldilli, B. (2012). It is due to very this reason that firms are always focused to ever 
changing present and future needs of customers. Employees perceive that a high quality product or service meeting and exceeding customers' expectations is surely a true reflective of the seriousness and the level of customer focus practiced in an organization which leads to enhanced business, profitability and in turn the organizational effectiveness. The same is in line with the study of Esin Sadikoglu, Hilal Olcay (2014).

\section{Education \& Training}

Training and development is an important quality management practice and determinant of organizational effectiveness Imparting of quality training and learning leads to an effective and efficient organization. This is compatible with results of the study by Kannan, V.R. and Tan, K.C. (2005), as discussed in Literature Review. Infect, training is an investment and it should not be considered as an expense, reason being much of the training cost is recovered through improved performance of employees. The investment made for employee training and knowledge transfer certainly has positive influences on organizational effectiveness. Most of the employees perceive that training is the backbone for successful implementation of quality management practices and thus significantly contributes towards organizational effectiveness. Employees view training as linchpin for successful implementation of QMS in the organization, undertakes training recurrently, undertakes evaluation of the training imparted to the employees, allocates substantial funds for training and that is why generally employees are more productive and satisfied with the training and education system followed in the organization. These findings are also supported by Saman, Y. (2012).

\section{Continuous Improvement}

Continuous improvement is a gradual never-ending change based on a Japanese concept called Kaizen to improve processes, procedures, operations so as to improve the desired results, products or services leading to enhanced organizational effectiveness as supported by Thessaloniki (2006). Once organizations adopt this particular quality management practice, they are principally firm believer of the view that all sorts of improvements can be undertaken provided that people involved in bringing a change are motivated and ready to undergo the hard work and the labour associated with happening of the desired change leading to achievement of the end objectives and organizational goals, thus significantly contributing towards organizational effectiveness.

\section{Team Work}

Team work is another determinant of this research to ascertain its role towards organizational effectiveness. Mostly, employees perceive it to be very beneficial in achieving the set goals and objectives. They consider it very crucial for the business and value it as if it is bread and butter for them. This is also matching with the results of study undertaken by Mazida Ahmad et. al. (2014). The reason being, if a team work spirit prevails in the organization it helps in creating a conducive environment which encourages variety of teamwork factors among team members, i.e. cohesion, cooperation, respect, pride, commitment, confidence, adaptability, talent, management support etc. Teamwork develops trust amongst team members which motivates them to cooperate with each other irrespective of any personal differences between them for the sack of the larger interests of the organization as supported by Ata ur Rahman, (2015). The efficiency of organization increases due to teamwork that increases business profitability. Employees also perceive that team work is vital w.r.t ensuring PQMS implementation and hence meaningfully contributes towards organizational effectiveness. 


\section{Top Management Commitment}

Top Management is an important quality management practice which has been studied in this research and influences the perception of employees with regard to organizational effectiveness. Since Top management is always concerned about meeting customers' requirements and organizational objectives, therefore hefty commitment from their end is essential for effective implementation of quality management within the organization as propounded by many gurus and researchers including Juran (1988), Gryna (1993), Saraph (1989), Flynn (1994), Ahire (1996), Anderson (1995). Employees can conveniently distinguish the level of commitment of the top executives through their visible behavior and actions. The time spent by the top management in dealing with quality related issues is again an obvious way of judging seriousness and resolve of top management in promoting importance of quality which ultimately contributes towards organizational effectiveness. As per employees' perception, top management is committed towards implementation of quality management system, promoting importance of quality, utilizing various quality tools and practices and taking right decisions in line with the quality policy, goals and objectives of the organization as advocated by Juran (1988), and Gryna (1993). All these steps significantly contribute towards organizational effectiveness.

\section{CONCLUSION}

This research concludes that the perception of most of the employees working at KS\&EW about the 'Organizational Effectiveness' largely depends on all five selected determinants for this research. The results have also been duly supported by the studies of various researchers as mentioned in discussion section. In can be generally concluded that as per employees' perception, the organization is paying attention towards customer focus as a quality management practice so that organization could succeed in its objectives for increased customer satisfaction, sustained business growth, profitability and enhanced customer base and retention. Employees perceive the focus of the organization towards education and training as a quality management practice as positive and regard training as backbone for successful implementation of QMS, conducts training and post training evaluation regularly and bears requisite training expenses etc. Continuous improvement has significant influence on organizational effectiveness. It is evident from the replies of the respondents that majority of workforce agree that the organization is well aware of the importance of continuous improvement and that it takes all measures that contributes towards continuous improvement of the organization. It is also concluded that the organization is focused towards team work and considers it highly useful w.r.t successfully achieving end objectives of the organization through maintaining a conducive environment for effective team work spirit. Majority of the employees appreciate the level of commitment of the top management which leads to organizational effectiveness. Hence, it can be concluded that perception of employees towards organizational effectiveness is influenced by all five quality management practices considered for this research.

\section{RECOMMENDATIONS}

Following measures are recommended for further improvement of quality standards at KS\&EW:

- $\quad$ Emphasis on customer focused approach be continued with vigor to maintain sustained customer satisfaction for enhanced customer base and retention on long term basis.

- $\quad$ Education and Training programs be strictly followed on recurrent basis; being beneficial to the organization and the employees alike.

- $\quad$ Effective enforcement of continuous improvement mechanism be maintained for efficient identification of sources of wastes/ reworks, leading to increased organizational effectiveness. 
- $\quad$ Frequent conduct of team building exercises may be ensured for development of the much cherished team spirit amongst employees.

- Top management of KS\&EW should remain committed towards effective implementation of quality management system within the organization.

\section{SUGGESTIONS FOR RESEARCH IN FUTURE}

In this research, only five Quality Management practices were examined to see their influence on employees' perception. Moreover, research was limited to only one industry i.e. KS\&EW due to paucity of time and other resources. Future scholars desirous of undertaking research in this field may study other components of quality management practices, particularly with respect to shipbuilding industry. A similar research may be undertaken in other organizations of the manufacturing industry.

\section{REFERENCES}

Abdul Rahman, M.N. and Tannock, J.D.T. (2005), "TQM Best Practices: Experiences of Malaysian SMEs", Total Quality Management Journal, Vol. 16 No. 4, pp. 491-53.

Abdul Talib, H.H, Mohd Ali, K.A. \& Idris, F., (2014),"Critical Success Factors of Quality Management Practices Among SMEs in the Food Processing Industry in Malaysia", Journal of Small Business and Enterprise Development, Vol. 21 Iss 1 pp. 152 - 176. Doi:1.118/JSBED-1-213-162

Ali Bakhit Jaafreh (2012). The Effect of Quality Management Practices on Organizational Performance in Jordan: An Empirical Study. International Journal of Financial Research.doi:10.5430/ijfr.v4n1p93.

Al-Shobaki, S.D., Fouad, R.H. and Al-Bashir, A. (2010), "The implementation of total quality management (TQM) for the banking sector in Jordan", Jordan Journal of Mechanical Industrial Engineering, Vol. 4 No. 2, pp. 304-13.

ASQ, The Global voice of Quality. Continuous Improvement. Retrieved from website: https://asq.org/(dated 20.1.2017)

Ataur Rahman (2015). The Role of a Team Leader in ALGI- Using Teamwork to Build aBetter Workplace. Retrieved from website: http://www.academia.edu/

Bjerke, R., Ind, N. and Paoli, D.D. (2007), "The impact of aesthetics on employee satisfaction and motivation", Euro Med Journal of Business, Volume 2 No. 1, pp. 57-73.

Cervená, K. (2011). Effectiveness of Education in the Slovak Republic. Paper presented at the Humanization of Education at Technical Universities Scientific Papers Proceeding, Bratislava.

Chong, V.K., and Rundus, M. J. (2004), "Total quality management, market competition and organizational performance", The British Accounting Review, Vol 36 No. 2, pp. 155-172.

Corredor, P., and Goñi, S. (2011), “TQM and performance: Is the relationship so obvious?”, Journal of Business Research, Vol 64 No. 8, pp. 830-838.

Danny Samson, Mile Terziovski (1998). The Relationship Between Total Quality Management Practices and Operational Performance. Journal of Operations Management 17, pp. 393-409.

Davood Gharakhani, Hossein Rahmati, Mohammad Reza Farrokhi, Arshad Farahmandian (2013). Total Quality Management and Organizational Performance. American Journal of Industrial Engineering, 2013, Vol. 1, No. 3, pp. 46-50.

De Vries, H., and A. De Jong. 2002. Dutch study gets up close and personal to ISO- 9000 in use. ISO Management Systems, 2 (3): 35-8.

Department of Trade and Industry. (2000). Quality Management System. Retrieved from Department of Trade and Industry website: http://www.dti.gov.uk/ quality/qms 
Diamantopoulos, A. and Winkelhofer, H. M. (2001), "Index construction with formative indicators: an alternative to scale development", Journal of Marketing Research, Vol 38, pp. 269-277.

Dongli Zhang1 \& Sarah Jinhui Wu (2014).The Focus of Quality Management Practices: A National Culture Perspective. International Journal of Business and Management; Vol. 9, No. 2.

Esin Sadikoglu, Hilal Olcay (2014). The Effects of Total Quality Management Practices on Performance and the Reasons of and the Barriers to TQM Practices in Turkey. Advances in Decision Sciences, Volume 14,pp. 143.

Faisal, T., Rahman, Z. and Qureshi, M.N. (2011), "Analysis of interaction among the barriers to total quality management implementation using interpretive structural modeling approach", Benchmarking: An International Journal, Vol. 18 No. 4, pp. 563-587.

Flynn, B.B., Schroeder, R.G., \& Sakakibara, S. (1995). The Impact of Quality Management Practices on Performance and Competitive Advantage. Decision Sciences, 26(5), pp. 659-691.

Fotopoulos, C.B. and Psomas, E.L. (2009), "Impact of 'soft' and 'hard' TQM elements on quality management results", International Journal of Quality \& Reliability Management, Vol. 26 No. 2,pp. 150-163.

Fotopoulos, C.B. and Psomas, E.L. (2010), "The structural relationships between TQM factors and organizational performance", The TQMJournal, Vol. 22 No. 5, pp. 539-552.

Giron Kamonja, Yan Liang, Muhammad Tayyab Sohail, Shahzad Ahmad Khan (2014). Quality Enhancement of Corporate Management Systems: An Overview of Best Management Practices. Journal of Service Science and Management, Volume 14, pp. 302-312.

Gray, Larson, \& Desai (2010). Project Management: The Managerial Process. 4th ed. New Delhi, Tata McGraw-Hill.

Greg Baker (2014, November). Developing Customer Focus. Retrieved from website: http://www.advanceconsulting.com/blog/developing-customer-focus/

Gremyr, I., \&Elg, M., (2014), A Developmental View on Implementation of Quality Management Concepts; International Journal of Quality and Service Sciences, Volume. 6 Issue 2/3 pp. $143-154$.

Jaafreh, A.B. and Al-abedallat, A. Z. (2013), "The Effect of Quality Management Practices on Organizational Performance in Jordan: An Empirical Study". International Journal of Financial Research, Vol. 4 No. 1, pp. 93-109.

Jānis Priede, (2012), "Implementation of Quality Management System ISO 9001 in the World and Its Strategic Necessity", Procedia - Social and Behavioral Sciences, Volume 58, 12 October 2012, Pages 1466-1475.

Jorge Morales Pedraza, (2014, May). What is organisational effectiveness? How an organization could achieve it? Retrieved from https://www.researchgate.net/ post/What_is_organisational_effectiveness_How_an_organisation_could_achieve_it.

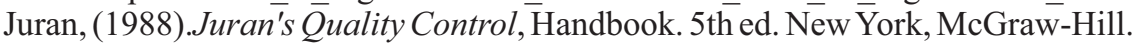

Kannan, V.R. and Tan, K.C. (2005), "Just in time, total quality management, and supply chain management: understanding their linkages and impact on business performance", Omega, Vol. 33 No. 2, pp. 153462.

K. Shahriar Iqbal, N. M. Golam Zakaria and Kh. Akhter Hossain, (2013). Identifying and Analysing Underlying Problems of Shipbuilding Industries in Bangladesh. Journal of Mechanical Engineering, Volume 41, pp. 53 - 77.

Kate Leggett, Stephen Powers, Ian Jacobs, Maxie Schmidt-Subramanian, Arelai Ephraim, Peter Harrison (2016). The Future of Customer Service. Retrieved from web site https://www.forrester.com/report/Trends+2016+The+Future+ Of+Customer+Service/-/ERES61372.

Kim-Soon Ng, (2012). Quality Management and Practices.InTech Publishers. DOI:10.5772/2346 ISBN 978-953-51-0550-3

Lisa McQuerrey (2010). What Are the Benefits of Teamwork on Organization Effectiveness? Retrieved from website: http://www.smallbusiness.chron.com/ benefits-teamworkorganization-effectiveness-78220.html 
Luke Talbot, (2016). Importance of Organizational Effectiveness to Success in Fast Changing Markets. Retrieved from website: https://www.questback.com/ blog/the-importance-oforganizational-effectiveness-to-success-in-fast-changing-markets

Mazida Ahmad, Vian Abdulmajeed, Mazni Omar, Azman Yasin, Fauziah Baharom, Haslina Mohd, Norida Mohd Daru (2014). Examining the Influence of Team Work Factors on Team Performance for Software Development in Telecommunication Industry.

Mohamad Kamal, Mohamad Dasuki\& Dr. Rizal Razalli (2013). The Research Study in Quality Management for a Ship Construction Company. International Journal of Science and Research (IJSR) ISSN (Online): 2319-7064 Index Copernicus Value (2013): 6.14 | Impact Factor (2013): 4.438.

Murali Chemuturi (2013). Requirements Engineering and Management for Software Development Projects. New York, Springer Science+Business Media.

Nursyamimi Shaari et al. (2014). Practices for Project Quality Management Systems (PQMS) in Construction Project. Jurnal of Teknologi, (Sciences \& Engineering) 77:26, pp. 69-76.

Organization for Standardization. (2015). Quality Management Principles. Retrieved from International Organization for Standardization. Retrieved from website: http://www.iso.org/iso/pub100080.pdf

Paul Cole-Ingait, (2010). The Role of Operations in Organizational Effectiveness. Retrieved from http://smallbusiness.chron.com/role-operations-organizational-effectiveness-73178.html

Rawan Al-Ettayyem\&Zu'bi M. F. Al-Zu'bi, (2015). Investigating the Effect of Total Quality Management Practices on Organizational Performance in the Jordanian Banking Sector. International Business Research; Vol. 8, No. 3, pp. 88-102.

Saman, Y . (2012). Total quality management in Sri Lankan service organizations. The TQM Journal, 24(6), 505-517. http://dx.doi.org/10.1108/17542731211270070

Saravanan, R. and Rao, K.S.P. (2007), "The impact of total quality service age on quality and operational performance: an empirical study", The TQM Magazine,Volume, 19No.3,pp. 197-205.

Shiv kumar Sharma1, Shivanand Vishnu Gupta, Rahul Singh (2014). Implementation of TQM for Improving Organizational Effectiveness. International Journal of Application or Innovation in Engineering \& Management (IJAIEM), Volume 3, Issue 9.

Tari, J. J., Molina, J. F., \&Castejon, J. L. (2007). The Relationship between Quality Management Practices and Their Effects on Quality Outcomes. European Journal of Operational Research, 183(2), pp. 483-501.

Thessaloniki, (2006).Kaizen Definition \& Principles in Brief: A Concept \& Tool for Employees

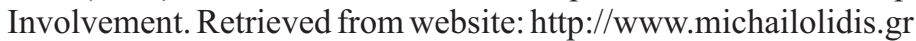

Vidyarthi, R., Dronavajjala, C.S. and Singh, D. (2009), "Strategic framework for implementing TQS in service organization", 5th International Working Conference on TQM, ABV-Indian Institute of Information Technology and Management Gwalior, available at: www.dronavajjala.Oceansfree.com (accessed 10 June 2011)

Zehir, C., Ertosun, Ö., Zehir, S., \& Müceldilli, B. (2012). Total quality management practices effects on quality performance and innovative performance. Procedia Engineering, 41, 273-280. 